\title{
Ütopik Sosyalizmde Yönetim Anlayışı
}

\author{
Harun BÍÇAKCI
}

\begin{abstract}
Özet
İyi bir yerde iyi bir şekilde hayatını sürdürme isteği her zaman var olagelmiştir. Geçmişten günümüze insanlar iyi bir yaşama kavuşma arzusu içinde kimi zaman göç yollarına düşmüş kimi zaman da yeni bir yönetim anlayışını benimsemiştir. Bu noktada da daha iyi bir yaşam vaat eden kurgular insanların zihinlerinde ve eserlerinde hep yer almıştır. Bu bağlamda, bu mutluluk arayışlarının kavramsal olarak nitelendirilmesi olarak baktı̆̆ımızda ise "ütopya" kavramı karşımıza çıkmaktadır.

Tarihi ve kültürel süreçte ütopyaların birbirinden çok farklı yaklaşımlar tarafından çeşitli şekillerde ele alındığı görülmektedir. Bu ütopik kurgular içine dahil olduğu düşünce akımlarının karakterine bağlı gelişen olumlu-olumsuz çeşitlemeleriyle yaşam pratiğini de etkilemiştir. Bu noktadan hareketle bu çalışmada bir başka boyut olarak ütopyalardaki yönetim düşüncesinin ütopik sosyalistler özelinde analiz edilmesi amaçlanmaktadır. Bu çerçevede çalışma iki bölümden oluşmaktadır. Birinci bölümde, ütopya ve yönetim arasındaki ilişki analiz edilmektedir. İkinci bölümde ise ütopik sosyalizmin önemli temsilleri arasında olan Saint-Simon, Fourier, Proudhon, Godwin ve Kropotkin'in düşünceleri karşılaştırmalı olarak derinlemesine irdelenmektedir.Bu hedefe ulaşmak için yerli ve yabancı literatür taraması tekniği kullanılmaktadır. Araştırma bu literatürün değerlendirilmesi, analizi, yorumlanması ve betimlenmesine dayanmaktadır.
\end{abstract}

Anahtar Kelimeler: Ütopya, ütopik sosyalizm, yönetim

\section{Administrative Thought In Utopian Socialism}

\begin{abstract}
There has always been a desire to live a good life in a good place. From the past to the present, people have fallen into migratory paths sometimes in the desire to have a good life and sometimes adopted a newunderstanding of administration thought. At this point, the fictions that promise a better life have always been in the minds and works of people. The concept of "utopia" comesout as a conceptual qualification of these searches of happiness.

In the historical and cultural process, utopias are handled in a variety of ways by very different approaches. These utopian fictions have also influenced the practice of life with the positive-negative variations that are attributed to the character of the movements of thought. From this point of view,as another dimension, it is aimed to analyze the administration thought in utopias within the context of utopian socialists. In this framework, the study consists of two parts. At first, the relation between utopia and administration is analyzed. In the second part, the thoughts of Saint-Simon, Fourier, Proudhon, Godwin, andKropotkin, which are important representatives of utopiansocialism, are examined in depth. Literature review technique is used.
\end{abstract}

Keywords: Utopia, utopian socialism, administration

${ }^{1}$ Arş. Gör., Ondokuz Mayıs Üniversitesi, İktisadi İdari Bilimler Fakültesi, Siyaset Bilimi ve Kamu Yönetimi Bölümü, harunbicakci@gmail.com 


\section{Giriş}

İnsanların mutlak iyiliğe ve mutlak mutluluğa olan özlemleri sürekli zihinlerdeki yerini korumuştur ve halen korumaktır. İyi bir yaşam ve hayattan lezzet alma isteği ve beklentisi teori ve uygulamada bizleri arayışlara sevk etmektedir. Düşünce dünyasındaki bu arayışlar kendini hem edebi eserlerde hem de siyasi ve felsefi eserlerde göstermektedir. Bu mutluluk arayışlarının kavramsal olarak nitelendirilmesi olarak baktığımızda ise 'ütopya' kavramı karşımıza çıkmaktadır.

Ütopya, tanım olarak_incelendiğinde hem hiçbir yer hem de iyi bir yer olarak ifade edilişi görülmektedir (Kumar, 2005:9). Ütopya kelimesi bütün dünya dillerine İngiliz yazar, hukukçu ve devlet adamı Thomas More'un aynı adlı kitabından geçmiştir. Yunanca ou (değil) ve topos (yer) kelimelerinden, 'hiçbir yerde olmayan' anlamında türetilmiştir (Avc1, 2006:15). Ancak kavramın tanımlanışına bakıldığında farklı yaklaşımlardan söz edilebilir.

$\mathrm{Bu}$ bağlamda, Türk Dil Kurumu (TDK) ütopyayı "gerçekleştirilmesi imkânsız tasarı veya düşünce" olarak tanımlarken (tdk.gov.tr) Felsefe Sözlüğünde ise ideal ya da yetkin toplum; ideal bir toplum düzeni ya da yönetim biçimi ortaya koyan tasarı olarak ifade edilmektedir (Cevizci, 1999:880). Bir başka deyişle "salt düşüncede de olsa içinde yaşayanlara eşitlikçi, doğru, haktanır, yetkin bir düzen içerisinde kötülüklerden arındırılmış mutlu bir yaşam sürmeyi vaat eden kurgusal ve ülküsel kusursuz toplum tasarısı: düşülke ya da düşülkü olarak da tanımlanabilir.” (Güçlü vd., 2003:1507). Sosyolojik manada ise "kusursuz bir toplumu ya da ideal bir devleti ifade eden hayali bir kurgudur" (Tandaçgüneş, 2013:19). Bu bağlamda, her sosyal öğreti, mevcut şartlardaki rahatsızlığın ve huzursuzluğun kaynağı olan düzeni değiştirmek ve bu kurulu düzene yeniden biçim vermek isteyeceğine göre, toplumun ileride alacağ 1 ideal durumu dile getirir. $\mathrm{Bu}$ bakımdan her sosyal öğretiye bir çeşit 'ütopya' denilebileceği de savunulmaktadır (Avc1, 2006:16). Kumar'ın da vurguladığı gibi ütopyanın iyi bir yaşama bakış açısı içinde yer bulduğu bugünün gerçekliğinden etkilenmektedir. Başka bir deyişle, ütopyacıların kâhinlik yetenekleri yoktur; görüşleri içinde yaşadıkları toplum biçimi tarafından sınırlanır (2005:79). Ütopyalara ilişkin böylesi betimlemeler ve zengin düşünsel yaklaşımlar toplumların tecrübe ettiği fiili durumla yakından ilgilidir. Sonuç olarak, kavram birçok düşünürü ve içinden doğduğu toplumları da çeşitli derecelerde etkilemiş ve etkilemeyi sürdürmektedir.

Bunların neticesinde de ütopyalar, birbirinden çok farklı yaklaşımlar tarafından çeşitli şekillerde ele alınmış, içine dâhil edildiği düşünce akımlarının karakterine bağlı gelişen olumlu-olumsuz çeşitlemeleriyle yaşam pratiğini etkilemiştir: Totalitarizm, Hıristiyanlık düşü, Faşizm, Saint-Simonculuk, Marx, Feminizm, 1968 kuşağ1 ve cinsel özgürlük, sanal dünyalar, aydınlanma ideali, komünizm, devrimci ütopik kurgular, ütopik sosyalizm, 1789 Fransız Devrimi, kurgu olarak bilim ve siyaset, Konumlanışç1 Enternasyonal, Bauhaus, Dada akımı, toplumsalcı okul, proleter kültür gibi birbiriyle içerik olarak çelişen 
kişilere, düşüncelere ve yönelimlere sözcülük etmiştir (Bakır Şen, 2006:3). Olumsuz ve olumsuz örnekleriyle yönetenlerin ve yönetilenlerin hayatını etkilemekte ve düşüncelerini yön vermektedir. $\mathrm{Bu}$ farklı yönetim algılarını da beraberinde getirmektedir.

Bu noktadan hareketle bu çalışmada bir başka boyut olarak ütopyalardaki yönetim düşüncesinin analiz edilmesi amaçlanmaktadır. Diğer bir deyişle, ütopyalarda kendine yer bulan yönetimin özüne işaret etmeyi hedeflemektedir. Bu hedefe ulaşmak için yerli ve yabancı literatür taraması tekniği kullanılacaktır. Araştırma bu literatürün değerlendirilmesi, analizi, yorumlanması ve betimlenmesine dayanacaktır. Bu çerçevede çalışmada ütopyalardaki yönetim düşüncesi iki bölüm altında incelenecektir. Birinci bölümde öncelikle ütopya ve yönetim arasındaki bağ üzerinde durulacaktır. İkinci bölümde ise önemli ütopik sosyalistler olan Saint-Simon, Fourier, Proudhon, Godwin ve Kropotkin'in düşünceleri karşılaştırmalı olarak ele alınmaktadır.

\section{1. Ütopya ve yönetim}

Yönetim olgusuna toplumsal ve tarihsel bir perspektifle yaklaşmak mevcut sorunların çözümünde ve ütopyacılığa yaklaşımda önemlidir. Yönetim, tarihle ilgilenmeksizin ortak hedefleri gerçekleştirmek için işbirliği yapan grupların faaliyetleri olarak tanımlanabileceği gibi, insanlık tarihi ile birlikte ortaya çıkmış bir beşeri ilişkiler olayı ve sosyal bir ihtiyaçtır sözünü kabul etmek mümkün olur (Ayman Güler, 2011:22). "Yönetimin özü, her biri sırasıyla diğerini zorunlu olarak yaratan üç kurucu unsurdan oluşur: işbölümü, otorite ve hiyerarşi.” (Fişek, 2005:87'den aktaran, Ayman Güler, 2011:34). Diğer bir deyişle, bu çalışmada yönetim olgusu sadece idare perspektifiyle daraltılmamıştır. Otorite ve hiyerarşiyi, tahakküm içeren ve bunların ütopyalardaki konumlanışı analiz edilmektedir.

Öncelikle bu çerçevede ütopyaların yazılış amaçlarının yönetim ve yöneticilerle doğrudan bağlantılı olduğu ifade edilmelidir. Hatta ütopyalar mevcut olanın yanında bazen de toptan yönetim olgusunun karşıtlığını yansıtır. O halde şu soruyu sorulabilir; kendi dönemlerinin yönetim biçimleri iyi olsaydı ütopyalar meydana çıkabilir miydi? Buna göre toplumun içinde bulunduğu şartlar, ihtiyaç duyulan şeylere insanları yöneltmektedir. Bir başka deyişle ütopyalar, toplumsal gerçekliğe ve onun gelecek üzerindeki yansımasına bakmaktan kaçınmayan eleştirel bir yönetsel girişimin tezahürleridir (Avcı, 2012b:242). Örneğin, Thomas More ve Tommaso Campanella'nın yaşadığı dönemlerde, Rönesans, Reform ve Hümanizmin etkisiyle, teokratik ve monarşik yapıların kırılma yaşadığı süreçleri görmekteyiz. $\mathrm{Bu}$ her üç dönemde de bir arayış söz konusudur ve bu sebeple de iki ütopya da dönemlerine karşı bir başkaldırı niteliğine sahiptir.

Özellikle bunalım ve kriz dönemlerinde çokça tartışılan yönetsel konularda, 'var olan' sistemin eksiklikleri, aksaklıkları hesaba katılarak 'ideal toplum', 'ideal devlet' ve 'ideal sistem' modelleri oluşturulmaya çalışılmıştır. İdeal devlet tasarımları, bir anlamda "gerçekleştirme arzusundan ya da 
kaygısından uzak" var olanın eleştirisidir. Bu ütopik tasarımlar kurgulanırken devleti oluşturan sosyal, siyasi, hukuki, ekonomik, dini, mimari etkenler göz önünde tutularak, sosyal, siyasal, hukuki, ekonomik, mimari gibi birçok konuda düzenlemeler tasarılara dahil edilmiştir (Şan, 2010:1). "Tüm siyaset felsefesi, 'egemenlik', 'diyalektik', 'genel irade', 'kuvvetler ayrımı', 'kamuoyu', 'ortak çıkar' gibi kurgularla uğraşır. Kurgu, tüm siyasi teoriyi nasıl niteliyorsa, ütopya yazımını da öyle niteler.” (Davis, 1983:17'den aktaran Kumar, 2005:49). Bunalım ve kriz dönemleri, toplumun ve yönetim sisteminin topyekün olarak alt üst olduğu ve toplumsal durumun ve sistemin nasıl rayına oturtulabileceği üzerine tasarılarla bütünlük içinde kurgusal olarak uğraşılması bağlamında düşünürlerin en faal olduğu dönemlerdir.

İster geleneksel isterse klasik ütopyalar olarak adlandırılsın bu eserler yaratıcı bir azınlığın ürünüdürler. Eğer bu azınlık ütopyaları üretmeseler genel ve yaygın bir bilince hiçbir zaman süzülüp yerleşemeyeceği de ileri sürülmektedir. Yönetsel düşünceyle ilintili olarak bakıldığında ise özellikle son iki-üç yüzyıldaki ütopyaların çoğu eğer rasyonalist değilse, en azından sekülarist ve açıkçası üst seviyeye sahip düşünürlerin eserleridirler. Ayrıca, yönetim düşüncesinin yansıması olarak klasik ütopyalardaki temel unsurlardan birisi de umutsuzca parça parça, geçici ve denge güdücü biçimde bir geri bir ileri şeklinde adım atmak değil bütüncül bir melioristik (dünyanın daha yaşanabilir hale getirilebileceğine olan inançla) reformun gerçekleştirilme olasılığına olan inançtır (Brinton, 1965:352).

Diğer yandan ütopyalardaki yönetsel kurgular dönemlere göre de farklılıklar arz etmektedir. Örneğin, özellikle 16. ve 17. Yüzyıllardaki ütopyalar daha hiyerarşik ve otoriterdirler. Kanunlar bu dönemlerdeki ütopyalarda insanların iyiliği için onlara dikte edilmektedir. Diğer ütopyalarda ise iyi ve mutlu yaşam bir evrim süreci içinde daha yüksek standartlara ulaşmaktadır. Ütopyacı bu hayatın çekilemez olduğuna ağıt yakar ve daha iyi bir yönetim şeklinin olabileceğine inanır. Bizim bütün başarabileceklerimiz savaşlar, suçlar, tecavüz vb. olmamalı denilmektedir. Bu bazı insanlar için biraz özgürlük pahasına bile olsa gelişmenin ve ilerlemenin zorundalığı belirtilir. Çünkü öldürme, tecavüz etme, soygun yapma özgürlükleri olamaz (Sargent, 1982:584). Bu ifadelerden de anlaşılacağı üzere ekolojik krizlerin çözümü için gerekli olan hiyerarşinin ve tahakkümün hiçbir yerde ve hiçbir şekilde olmadığı bir toplum düzenidir. Bunun için de insanı ve doğayı birbirinden ayrı düşünmemek gerekmektedir (Yıldırm, 2017, 302). Bu noktada da yönetim boyutunda eşitlik düşüncesinin yanında adil yönetim vurgusu daha fazla öne çıkarılmaktadır denilebilir.

Bir diğer nokta olarak yönetsel şekillenim olarak baktığımızda, ütopik kurgular ilk olarak küçük bir bölge olarak tasarlanmaktadır; örneğin, dünyanın bozuk düzeninden izole edilmiş bir adada tasarım kurgulanır. Çoğu ütopyacı, genel politikaların bütün evren için geçerli olabileceği bir bütün olarak iyiliği ortaya koyacak örnek kentler hayal etmiştir ('trialboroughs' veya cantonsd'esquisse olarak isimlendirilen) (Hecht,1988:50). Başka bir deyimle, medeniyetlerin yeşerdiği zemin de olan kentlerin kuruluşunda, ortaya 
çıkışında elde edilen ürünlerin dağıtımı ile kentsel mekanda yaşayan insanların nasıl bir düzen içinde ve huzurlu şekilde yaşayabileceği sorusuna cevaben ütopik kent kurguları öne çıkmaktadır. Böylelikle kent beşiğinde farklı seslerden farklı ninniler eşliğinde yeni kent ütopyaları büyümekte ve olgunlaşmaktadırlar.

Sonuç olarak, ütopya ve yönetim düşüncesi arasındaki ilişkiye bakıldığında insanlık tarihi boyunca mutluluk vaadi olan ütopyalarda daha iyi bir düzen ve yönetim isteği ve bu nasıl olabilir sorusunun cevabının arandığı, değişik yönetim şekillerinin bulunduğu görülmektedir. Alternatif bir yönetim biçimi olarak ütopyalar dikkatleri çekmektedir. Diğer bir deyişle, ütopik eserlerin yazılış amaçları yönetim ve yöneticilerle doğrudan bağlantılıdır. Dahası, ütopyalarda yönetim karşıtlı̆̆ının yansıması söz konusudur. $\mathrm{Bu}$ noktada, döneminin yönetim biçiminden memnun olmayan ve yöneticilerin uygulamalarından bunalan filozoflar, arzuları ve hayalleri neticesinde kurguladıkları yönetim biçimini ve devlet modelini kimi zaman eserleriyle kimi zaman da fikirlerini eylemsel düzeyde hayata geçirmişlerdir (Avc1,2012a:380-381). Bir sonraki bölümde ise seçilmiş eserler 1şı̆̆ında ve seçili ütopik sosyalist düşünürlerin fikirlerinde nasıl bir yönetim tahayyülü olduğu üzerinde durulacaktır.

\section{2. Ütopik sosyalistler ve yönetim düşünceleri}

18. yüzyılda sosyal inşacılığın koşulları son derece elverişli idi. Aynı toplumun daha yüksek ve daha alt tabakalarında yer alan insanlar, geç mutlakiyetçiliğin politik, toplumsal ve kültürel durumundan tümüyle memnun değildi (Briefs, 1939: 32). Bu memnu olmama hali yeni düşünce ve teorilerin gelişimine zemin hazırladı. Bu zemin yeni ütopik kurguların da doğumunu şekillendirdi.

Bu noktada da 18.yüzyılın sonunda önemli birçok düşünce adamına göre acil görev, edebi ütopyalar yazmak yada çizmek değil, bilimsel-toplumsal teoriyi geliştirmekti. Bu nedenle de 19. yüzy1lda büyük oranda karşımıza ütopyacı teori olarak çıkar. Saint-Simon, Fourier, Comte; Spencer ve Marx'ın büyük sistemlerinde kendisini gösterir (Kumar, 2005:97). Böylelikle de bir bunalım döneminin, toplumsal ve yönetsel krizin sonucunda yeni bir düşünme biçiminin ve dünya algısının ortaya çıkışını görmekteyiz

Genel olarak bakıldığında, ütopik sosyalistler çalışmanın kutsallığına inanmaktadırlar. Çalışma hakkı devredilemez bir haktır ve devlet tarafından düzgün bir örgütlenme yoluyla garanti altına alınmak zorundadır. Ayrıca, devlet, Aydınlanma düşünürleri tarafından da önemle vurgulanıp tekrarlandığı gibi, bireyin ve toplumun dönüşümünde temel bir araç olan eğitimde de temel bir role sahiptir (Hecht, 1988: $51)$.

Dahası, bu dönemde insan aklının ve kusursuzluğunun sınırlı olduğu konusunda yaygın bir kuşkuya yol açan bilimsel ve teknolojik keşifler söz konusuydu. İnsan aklının gücü sonsuz görünüyordu ve bu inanç da genel bir özgüven ve iyimserlik ruhunun yükselişini sağladı. O günkü düşünürlerin çoğu, insan sınırlamalarının varlığını dikkate almadılar; bazıları, ölçülemez bolluk içinde, yeryüzünde sonsuz 
yaşamın tadını çıkarabilecek uyumlu insan toplumu olasılığı konusunda ikna olmuşlardı. Örneğin, Godwin sonsuz bir insan yaşamı olasılığını inancını benimsedi (Briefs, 1939: 32-33).

Sosyalizme evrilmeyle birlikte, ütopya tarihi açısından gerçekleştirilen en büyük katkı, arzulanan yeni toplum düzenini hayata geçirecek aktörün belirlenmesiydi. Buna göre, yeni toplum düzenini gerçekleştirerek, tersine çevrik toplumu ayakları üstüne kaldıracak aktör olarak 'işçi sınıfı' görüldü (Bal, 2010:7). Diğer bir deyimle, burjuvazi iktidara geldikten ve sanayileşme yerleştikten sonra yeni bir toplumsal lokalizasyonla yeni ütopyalar geliştirildi. Proleter ütopyalar burjuvazi ütopyalarının yerini aldı (Briefs, 1939:33). Diğer yandan, 1848 devrimi bu heterojen hareketi de polarize etti: ütopyacı vs. bilimsel; veya sosyalist vs. komünist. Ek olarak, 1848 olayları dini bir dil kullanımının önemli derecede yok etmesine karşılık, sosyalist düşünce dini ilhamdan aldığı dili kullandı (Hecht, 1988:51). Bu çerçevede bu bölümün devamında ütopik sosyalizmin öncüleri olan kişilerin ütopyalarındaki yönetime dair düşünceleri derinlemesine incelenmektedir.

\subsection{Saint-Simon ve Fourier}

19. yüzyıl filozoflarının ütopyaları, Thomas More’un başlattı̆ğ anti-kapitalist geleneği sürdürerek sanayi devrimiyle birlikte sosyalizme doğru evrilmişlerdir. Bu bağlamda, Saint-Simon ve Fourier, ütopyalarda düşlenen toplum düzeninin içinde yaşanılan 'an'da, üstelik 'reform'larla değil, 'devrim'le hayat bulacağını belirtirler. Bu çerçevede, Simon 'reform' kavramına 'gönülsüz önlem' adını vermektedir ve gönülsüz önlemler devri çoktan geçmişte kalmıştır. Bu noktada, Saint-Simon için çözüm ise bir an önce devrimin olmasıdır (Bal, 2010:5).

Ütopik sosyalistlerin üstlendiği kapitalizm karşıtı tepkinin belirleyici bir diğer özelliği ise sanayi devriminin yol açtığı kötü çalışma ve yaşam koşullarına karşı 'duygusal' bir tepki niteliği taşımalarıdır. $\mathrm{Bu}$ duygusal boyutun dile getirilen çözümlerin gerçekçilik ve uygulanabilirlik derecesini kaçınılmaz biçimde azalttığı belirtilmektedir. Başka bir deyişle, nereye gitmek istediklerini bildiklerini ancak istenilen yere nasıl gidileceği konusundaki fikirlerinin bulanık olduğu savunulmaktadır. İlk olarak Saint-Simon'a bakıldığında 'Bir Cenevreliye Mektuplar', 'Endüstri Sistemi', 'Endüstricilerin Elkitabı' ve 'Yeni Hristiyanlık' gibi yapıtları 1800'lü yılların ilk yarısında yayımlanmış olan düşünürün, sosyalizm, teknokrasi ve enternasyonalizm gibi çağdaş düşüncenin birçok eğilimine ilk kez değinen kişi olarak nitelendirilebileceği ifade edilmektedir (Şenel, 2001: 106).

Condorcet ve Aydınlanmanın diğer düşünürlerine koşut olarak, Saint-Simon'a göre tarih belirli nesneye, hedefe doğru doğrusal bir ilerlemeyi ifade etmektedir. Ona göre Altın Çağ insan irkının çocukluk emekleme evresinde değil, şu an bizim önümüzde durmaktadır. Saint-Simon için siyaset üretimin bilimidir. Dolayısıyla, onun için gerçek üreticiler, imalatçılar, yatırımcılar, mühendisler ve işçilerdir (Hecht, 1988: 52). Bir diğer açıdan değerlendirildiğinde, “alın terinle kazanacaksın vb. İncil'den püriten 
düşüncelerle idare eden burjuvaziye, Saint-Simon bir öğreti, bir teknokratik din kazandırdı ... üretimin övgüsünü yaparak toplumu endüstriyle tekrar örgütlemek istiyordu” (Bumin, 2013:71). Bu üretimle eş zamanlı olarak, Simon'a göre devletin ilk ve öncelikli görevi en yoksul ve en kalabalık olan sınıfın hayat şartlarının düzeltilmesidir. Bunu gerçekleştirmek için toplumdaki en önce gelen faaliyet olarak üretim, merkezi bir şekilde örgütlenecek, iş ordusundaki işçi mangaları, mühendis ve politekniklilerin emirleri altında bulunacaktır (Bumin, 2013: 72). Bununla birlikte, ütopik tasavvuru, sanatçı bir öncü grubun ön ayak olduğu sınıflı bir toplumsal yapısına ve sanat ve bilimin gelişimine dayalıdır (Tunç ve Kaya, 2012: 424). Bakıldığında Simon'un öğretileri burjuvaların ihtiyacı olan bir düşünsel yapıyı onlara kazandırdığı görülmektedir. Üretimi öne çıkarması bağlamında öğretileri burjuvazi tarafından daha çok dikkate alınmıştır denilebilir.

Bir diğer ütopik sosyalist olan Fourier'e bakıldığında ise, modern burjuvazinin vaatlerinin boş olduğunun ortaya çıktığı üzerinde durmaktadır. Çünkü üretimin artışıyla birlikte yoksulluk azalmak bir yana devamlı artmıştır. Üretim toplumsallaşmış, ama bu üretimin neticesinde ortaya çıkarılan zenginlik henüz toplumsallaştırılamamıştır. "Toplumsallaşmış üretim karşısında duran toplumsallaştırılamamış sahiplenme, başka bir deyişle 'kapitalist sahiplenme' olgusu, üretimin toplumsallaştırıldığı zamanlardan bu yana sürekli olarak krizle, bunalımla sonuçlanmıştır.” (Bal, 2010: 6). Böylelikle burjuvazi karı özelleştirmiş, maliyetler ise toplumsallaşmıştır.

$\mathrm{Bu}$ bağlamda Fourier'in sistemi bakıldığında Newton'dan esinlenilerek toplumsal hayata da uyarlanan Cazibe ve Evrensel Ahenk teorisini temel almaktadır. İnsanları hem kendi hem de toplumun çıkarlarına göre yönlendiren tutkulu çekim yasası Tanrı tarafından verilmiş sihirli bir değnektir. Ona göre, gerçek bir birlik bütün tutkuların sanayiye uygulanması sanatıdır. Kepler'in Tanrısal hareketi ilahi bir uyum olarak görmesi gibi, Fourier bütün tutkuları böyle mükemmel bir orkestranın ve uyumun öğeleri olarak görmektedir. Tarihi de bu çerçevede farklı dönemlere ayırmıştır: Eden- Cennet Bahçesi (monopoly dönemi); vahşilik (bireysel mücadele ve yarış dönemi); patriarşi (petty-küçük üretim dönemi); barbarlık (moyenne-orta, ortalama üretim dönemi); uygarlık (büyük ölçekli sanayi); 'guarantism' (semi-associationyarı birleşme, işbirliği); 'sociantism' (basit birleşme, işbirliği); ve Harmoni (Hecht, 1988: 64).

Başka bir deyimle, Newton'un evrene dair mekanik yorumuna karşın kozmosun yaşam ve gelişmeyle kaplı çok önemli bir organizma olduğu yaklaşımını geliştirir. Toplumsal gelişmenin tepe noktası olarak Ahenk, yalnızca uygarlığın baskıcı aracını parçalamakla kalmayacak nihayetinde bireylere tutkularının tam kurtuluşunu ve arzularının tam tatminini sağlayacak olan tamamıyla yeni toplumsal kurumların -özellikle Falanster kurumlarının- hâkimiyetiyle damgalanacaktır (Bookchin, 2013: 444-445). "Falanster ne kırsal bir köy ne de kalabalık bir şehir olacak, bunun yerine her ikisinin de erdemlerini birleştiren dengeli bir topluluk olacaktı. Tam olarak içinde en fazla 1700 ile 1800 kişi olacaktı ve 
Fourier'e göre bu, sadece insani bir ölçeğe izin vermiyor, aynı zamanda insanları, her bir bireyin arzularını tatmin etmesi için gerekli olan doğru sayıda tutkulu birleşimde bir araya getiriyordu". Falanstre "bütün ortakların pay sahibi olduğu bir kooperatiftir. Herkesin çalışmasa bile hayatını sürdürebilmesi için gerekli asgari gereksinimi karşılanmaktadır” (Bumin, 2013: 81).

Fourier'e göre, 'tutkuların çekim yasası' politika ve ahlak anlayışımızı da yerle bir etmelidir (Bumin, 2013:80). Ayrıca, toplumsal özgürlüğün kaderini kişisel özgürlüğe bağlı görmekte ve toplumda baskının yok olması insan ruhunda baskının ortadan kaldırılmasıyla eş zamanlı olarak yer almalıdır (Bookchin, 2013: 446). Bookchin'e göre, Fourier, kendi döneminin “en özgürlükçü, en özgün ve en önemli ütopyacı düşünürü ve en eski toplumsal ekolojisttir” ve geliştirdiği Falansteri çeşitlilik içinde birliği geliştirmeye dönük çabası bağlamında toplumsal bir ekosistem olarak görülebilir. Kendine özgü bir eşitsizlerin eşitliği kavrayışına sahip olduğu savunulmaktadır (Bookchin, 2013: 447).

\subsection{Proudhon, Godwin ve Kropotkin}

$\mathrm{Bu}$ noktada değinilmesi gereken ütopik sosyalistlerin geleneğini bir adım ileri götüren Proudhon, Kropotkin ve Godwin'in ortaya koydukları 'mutluluk vaadi' ve bunu gerçekleştirmek için önerdikleri yönetim modelidir. Büyük bir put yıkıcı olarak görülen ve Fransız işçi sınıfının da kurucularından biri olan Pierre-Joseph Proudhon (1809-65), bir hizmetçi ve fiçı yapan kişinin, bir proleterin oğludur. Görkemli şekilde izole edilmiş, paranoya ve çelişkilerle dolu olduğu ileri sürülen Proudhon, sosyalist düşüncenin en yüksek zirvesi olarak görülmektedir. Marx ile eşiti olarak tartışan belki de tek kişi olduğu da ifade edilmektedir (Hecht, 1988: 60-61). Düşüncelerinin yönetim boyutu açısından irdelediğimiz örneğin, sosyoekonomik alandaki temel soruları mülkiyete ve çalışmanın örgütlenmesine ilişkindir. 1849’daki Yönetimin Aslı ve Yönelimi başlıklı makalesinde şunları söylemektedir (Proudhon, 1992: 24):

"Bütün insanlar eşit ve özgürdürler: Yani toplum doğası ve tanımı gereği otonomdur ve yönetime ihtiyacı yoktur. Her vatandaşın faaliyet alanı, çalışmanın doğal paylaşımı ve mesleğin seçimi ile belirlendiğinden, toplumsal işlevler harmonik bir sonuç ortaya çıkaracakları bir bağlantı içinde olduklarından; düzen, herkesin özgür faaliyetinin sonucu oluşur; yönetim yoktur.”

Proudhon burada anarşiden bahsettiğinde bunun etimolojik manada tüm tahakküm sisteminin yokluğuyla kurulan bir toplum düzenini içeren bir rejim olduğuna işaret eder. Ona göre, hiyerarşiye ve hükümete dayanan bir toplum, düzen düşüncesinin birçok olası kavrayışlarından birini temsil eder. Örneğin, devletli bir toplum ilkel ve koşullu bir düzen fikrini temsil eder; gerçek manada rasyonel ve adil toplumsal düzene ancak bir insanın diğer insan üzerindeki her türlü baskısının tamamen ortadan kaldırılmasını sağlayacak bir sistemle ulaşılabilir (Simon ve Kuic, 1973: 21). Ona göre otorite insanoğlunun ilk toplumsal düşüncesidir (Proudhon, 1992: 26). Bu nedenle de şunları dile getirmektedir (Proudhon, 1992: 29-35): "Partilere son! Otoriteye son! İnsanların ve vatandaşların mutlak özgürlüğü! ... 
Kim nihayet şunu söylemeye cesaret edecek: Her şey halk için, her şey halk yoluyla, yönetimin kendisi de.".

Proudhon kariyerinin sonuna doğru ise devleti toplumsal yaşam için kesinlikle gerekli olarak görmekte ve onun halk tarafından kaldırılması ve nihai dönüşümü hakkında spekülasyon yerine yapılacak şey devletin varlığını kabul etmek ve sonrasında onun güçlerini dengelemek ve sınırlamak olduğunu vurgulamaktadır. $\mathrm{Bu}$ çerçevede, siyaset sadece ekonomiye indirgenemez düşüncesini benimsedikten sonra, Proudhon yönetsel düzen hakkındaki nihai modelini federal bir sistem olarak tasarlamaktadır (Simon ve Kuic, 1973: 23-24). Diğer bir deyişle, Proudhon'un özgünlüğü ve düşüncelerinin anahtarı ilerlemenin kararlı ve koşulsuz olumlanmasına uzanmaktadır. Ayrıca, "özgürlükçü ya da sözleşmeye dayalı yönetim sistemi, her gün otoriter yönetim sistemleri üzerinde yeni zaferler kazandığı için; sözleşme fikrini, politikadaki bütün hakim düşüncelerin üstünde tutmalıyız demektedir.” Bu bağlamda düzenlenmiş özgürlükçü yönetim sisteminin modelini içeren politik sözleşmeyi ise Federasyon olarak tanımlar (Proudhon, 1992: 41-42). Bu şekilde sözleşmeye dayalı olan federal toplum hiyerarşik değildir. Devlet ve onun parçaları arasındaki ilişkileri çözümleyen, eşit değiş̧im ilişkilerini içeren hiyerarşik olmayan bir birliktir (Simon ve Kuic, 1973: 26).

Öte yandan, Proudhon'ın Godwin gibi sözleşme yaklaşımını daha fazla radikalleştirmeye çalışmadığı, dikkatini merkeziyetçiliğe ve devletin vatandaşların hayat alanına yaptığı müdahalelere yönelttiğine işaret edilmektedir. Onun tasarladığı yönetsel anlayışta anarşinin sırf devletsizlik durumunu ifade eden bir kuram olmadığı, merkeziyetçi yapı yerine adem-i merkeziyetçi ve komünal örgütlenme/yapılanma şekillerini ve bir federalist yapının hayata geçirilmesi olduğu ifade edilebilir (Cantzen, 2015: 40). Ona göre federal sistem, kitlelerin galeyana gelmesine, her türlü demagojik iktidar hırsına bir son verir ve bu model cadde ve tribünlerin iktidarının ve başkentlerin çekim gücünün sona ermesidir (Proudhon, 1992: 44). Onun için "federasyon düşüncesi, kesinlikle, politik aklın şimdiye kadar eriştiği en yüksek seviyedir." (Proudhon, 1992: 45). Teorisi genel olarak "tarımsal-endüstriyel federasyon" olarak özetlenmektedir. Onun için temel ilke, toplumun mümkün olduğu kadar çok kararın merkezi olmayan yoldan alt birimlerce alınabilecek şekilde örgütlenmesidir. Bununla birlikte, devletin fonksiyonlarını, toplumsal fonksiyonlara aktarmak anlamında toplumsallaşmanın gerçekleşmesinden, diğer bir deyişle, “devletin toplum içinde emilmesi”nden bahseder (Cantzen, 2015: 102,103-105). Devletsizlik yerine piramidin altında görülen halkın karar mekanizmasında daha etkili olacağı şekilde devlet yönetiminin yeniden şekillendirilmelidir. Federasyon şeklinde aşağıdan yukarıya doğru bir örgütlenme tarzı da daha özgürlükçü ve daha az hiyerarşik toplumu ortaya koyar.

Bu noktadan hareketle, Proudhon'un üzerinde büyük bir etki bıraktığı düşünür olan Kropotkin'in düşüncelerine değinilmelidir. Kropotkin'in Karşılıklı Yardımlaşma (Mutual Aid) eserini Huxley’ın 
dişlerinde ve pençelerinde kan kırmızısı olan doğa tasvirine cevap olarak yazdığı da ifade edilmektedir. Diğer yandan, anarşistlerin tümüyle bireysel otonominin çekiciliğine veya olasılığına ilişkin ortak bir inanç paylaştığına dair görüş sahibi olduğu fikrine girilmemesine yönelik uyarı da dile getirilmektedir. Ayrıca Hobbes'un doğa durumuna benzer izole edilmiş, doğal insan gibi bir modele de sahip değildirler. Mikhail Bakunin ve Peter Kropotkin özellikle güçlü bir biçimde insanlar için tam otonominin bir anlam ifade etmediğini belirterek bunu eleştirmişlerdir. Diğer bir deyişle, onalara göre tümüyle bağımsızlık gibi bir şey geçmişte de yoktu ve ileride de söz konusu değildir. Çünkü erkekler ve kadınlar kaçınılmaz bir şekilde toplumsal varlıklar olmaları sebebiyle her zaman hemcinsleriyle karşılıklı bağımlılık içindedir (Fowler, 1972: 742). Sonuç olarak, insanın doğa ve hemcinsleriyle ilişkisindeki temel karakterin baskı ve tahakküm yerine karşılıklı bağımlılı̆̆ı ortaya koyduğu dile getirilmektedir.

$\mathrm{Bu}$ noktada, ütopyalarının gerçekleşmesinde anarşist öğretide insan ilişkilerinde baskı ve tahakkümün kaldırılması değerli bir yönetsel boyuttur. Kropotkin bu noktada birçok anarşist düşünürün benimsediği ideal bir düzene ulaşılmasının tahakkümden nihai olarak özgürleşme sayesinde olacağ görüşünün temsilcisidir. 19. yüzyıldaki anarşist ütopyacıları, düşünürleri gibi Kropotkin'e de insan davranışı hakkında sinizm olduğu günlerde dokunaklı olarak (ya da kızdırıcı şekilde) sıklıkla naif olduğu şeklinde davranılmıştır. Onların insan potansiyelinin olumlamaları içinde yaşadığımız pratik çağda (uygulama çağında) en korkunç suçlama ile karşılaştığı belirtilmektedir: gerçekçilik eksikliği (Fowler, 1972: 744-747). Karşılıklı yardımlaşma düşüncesinin arılar ve karıncalar vb. leri bir gerçekliği ifade edebileceği ancak ruhunda binbir arzu ve tutkuya barındıran insanın kendinden de vererek bu karşılıklı yardımlaşmayı nasıl sağlayacağı kuşkusu karşımızda durmaktadır. Yaşadığımız çağda bireyin kendi iyiliğiyle eşdeğer olarak genel iyiliği için de çaba gösterebileceği insanın potansiyeli düşünüldüğünde kuşkuyla karşılanmaktadır.

William Godwin'e göre ise ilerleme devlete boyun eğdirme yoluyla sağlanmaz, insanların aklın dikte ettiklerini ve yalnızca kendilerinin iyiliği takip ettiklerinde meydana gelir. Tam bireycilik (complete individualism) ve bütün bedensel ve tensel özellikle de cinsel sınırlamaların kaldırılmasının dayanışma ve evliliğin ortadan kaldırılmasıyla birlikte hiçbir suçun, hastalığın, savaşın ve hükümetin olmadığı bir ütopya durumu olacağını ileri sürmektedir (Morris ve Kross, 2009: xxxiii). Godwin'in geleceğe ilişkin ütopik bir vizyon çizdiği Siyasi Adalet Üzerine Bir İnceleme adlı eserinde zamanın toplumsal adetlerine ve okullarına yönelik saldırıyı da çalışmalarına dahil etmiştir. Godwin'in ve Kropotkin'in yazılarında en önemli varsayım doğanın büyük ölçüde bilinebileceğidir. Arzu ettikleri her şey bu epistemolojik iyimserlik üzerinde kuruludur. Bu doğa anlayışı bir diğer temel inanç için de faydalıdır. Onlar eğer bir şey “doğal” ise bir erdem içerdiğine varsaymaktadırlar. Onların doğa üzerine tüm bakışları doğanın düzen içerinde ve özgürlüğü kapısı olduğu iddiasını içermektedir. Kropotkin, devletçilerin bu kadar yasaya, 
cezaya ve polislere sahipken bilgiç bir şekilde düzenden bahsedebildiklerini merak etmektedir. Ona göre bunlar düzen bir düzen yokluğunun dişsal göstergeleridir (Fowler, 1972:748-749).

Diğer yandan, Godwin ve Proudhon, iyi bir toplumda kötü yönetimden ve görevi kötüye kullanmadan korkmuş ve suçluları etkisiz kılmak ve tekrar onlara olanak vermemek için cezalandırma ile onların kontrollerini önermektedirler. Ayrıca, Godwin ve Proudhon cezanın tüm tanımları içinde bunların bir otorite tarafından uygulanmasını kabul etmişlerdir. Herhangi biri diğerine acı yaşatabilir; ancak cezalandırıcı, yetkili ve otorite sahibi olmalıdır (Ritter,1975:69-71). Görüldüğü üzere, Kropotkin'in aksine Godwin ve Proudhon'ın yasaların düzenin sağlanması ve devamı için gerekli görmektedirler. Bu yasaları uygulayan bir otoritenin varlığını da düzenin varlığı adına benimsedikleri görülmektedir.

Kropotkin'nin yönetim anlayışına bakıldığında geleceğin ideal ve özgür toplumu Ortaçağın ademi merkeziyetçi ve federatif yapılarıyla benzerlik göstermektedir. Kısacası, toplumu hükümetsiz bir biçimde algılamaktadır: 'üyeleri arasındaki bütün karşılıklı ilişkiler yasalarla, seçilmiş ya da gönüllü otoriteler tarafindan değil, toplumun üyeleri arasındaki karş1lıklı anlaşmalar yoluyla ve toplumsal gelenekler ve alışkanlıklarla düzenlenir (kanunlar, alışılagelmişlikler veya batıl inançlarla değil, yüksek ideallerin istikrarlı büyümesi, bilimin ve buluşların ilerlemesiyle uyarılmış özgür yaşamın artan gereklerine göre devamlı gelişen ve sürekli düzenlenen anlaşmalar). Kropotkin ideal toplumun sürekli olarak değişim içinde olacağını çünkü onun yaşayan, gelişen bir organizmaya benzediğini önemle vurgulamaktadır (de Geus, 2014:868). Kropotkin'nin bu federatif yaklaşımı Godwin ve Proudhon ile benzerlikler içerdiği görülmektedir. Bakıldığında yönetsel olarak yukarıdan aşağıya değil aşağıdan yukarıya doğru bir yönetim modelini özgür yaşamın gerekliliğidir. Diğer bir deyişle, özgürlükçü ve anlaşmaya dayalı bir yönetim modelini vurgulamaktadırlar.

Diğer yandan, Kropotkin içinde yaşadığı dönemin kapitalist-devletçi toplumunu ve onu meşru kılan kurumlarını eleştirmektedir. Toplumun "herkesin herkese karşı”" doğal bir savaşımda olduğu düşüncesini reddeder ve bunun yanında devleti de bu mücadelenin zorunlu bir denge unsuru biçiminde değerlendiren liberal anlayışa da karşı çıkar. Kropotkin'e göre “insan ve topluma ilişkin bu saptamalar belirli bir tarihsel duruma ilişkin pek de yerinde olmayan genellemelerden ibarettir" (Cantzen, 2015:3031). "Herkesin herkese karşı" mücadelede olduğu düşüncesin kapitalist-devletçi toplumu ve kurumlarının yaşam süresini uzatmaktadır. Ona göre toplum yardımlaşmanın da söz konusu olduğu bir yapıdır. İnsanın doğa ve toplumla olan ilişkisinde karşılıklı yardımlaşma esas denge unsurudur.

Ayrıca, Kropotkin üretimin adem-i merkezileşmesini savunmaktadır. Mallar kentin etrafına eşit şekilde dağıtılmış ve bahçelerden ve alanlardan yürüme mesafesi uzaklığında olan küçük ölçekli fabrikalarda ve dükkânlarda üretilmelidir. Sonuç kadınlar ve erkeklerin tarımsal ve endüstriyel faaliyetleri birleştirebileceği ekoloji olarak sorumlu biçimlerde küçük ölçekli bir toplum olacaktır. Onun öngördüğü 
liberter yönetsel eğilim insani ölçeğe, bağımsız ve ekolojik olarak duyarlı tarımsal-endüstriyel komünlere doğru hareket etmektedir. Bu topluluklarda çalışma az, çeşitli ve uygun makul biçimde olacaktır. Kropotkin hem topraksal hem de siyasal adem-i merkeziyetçi yönetsel yapıyı desteklemektedir. Topraksal olarak eğilim özerk, otonom komün gruplarının, köylerin ve kasabaların oluşturulmasıdır. İşlevsel olarak ise, daha önceleri devlet tarafından yerine getirilen görevlerin çok sayıdaki kurumlara, birliklere ve geniş gruplara bırakılmasını tahayyül etmektedir. Doğal olarak, bu yeni toplum tasarımı bütün bu kurumların ve yapıların ekonomik, eğitsel, entelektüel ve sanatsal ihtiyaçların tatminliği adına işbirliği yaptığında evrim geçirecek ve gelişecektir. Bütün koşullar altında, bu birlikler, komünler ve geniş gruplar bütünüyle bağımsızlıklarını ve iç işılerini düzenleme hakkını koruyacaklardır. Bu nedenle, toplumun amacı 'birlik' (unity) veya ‘düzen' (order) değil, organik ve doğal ahenktir (harmony). Düzen, birlik ve istikrar, kanunlar ve boyun eğme araçlarıyla gerçekleştirilirken, bu doğal uyum iç içe geçmiş bütün ölçeklerdeki ve kademelerdeki federasyonlar arasında sonuçlandırılan çeşitli toplumsal grupların özgür anlaşmalarının sonucudur (de Geus, 2014:869-871).

Ona göre, hiyerarşik otorite yönetimin temelindeki toplum üyeleri arasında özgürlük yoksunluğuna yol açar. İyi insanlar üzerinde bile uygulanan hiyerarşik otorite lekelenmeye sebebiyete eğilimlidir. Otoritenin varlığı ve uygulanışıyla en iyi insanın bile kötü biri yapılacağını savunur. Çünkü hiyerarşik otorite yönetilen üyeler arasında uyumculuğu (conformity) ve itaati üretir. Cezalandırılma korkusu ve itaat, inisiyatif alma eksikliğine ve zihinsel köleliğe yol açar. Kropotkin bütün bireylerin merkezi bir etken olacağı özgür bir yönetsel tasarım önermektedir. Diğer yandan bu görüşleriyle de birçok radikal toplumsal ve siyasal düşünürü etkilemiştir; örneğin, William Morris, Aldous Huxley, Murray Bookchin bunlar arasındadır (de Geus, 2014:869-875). Sonuç olarak, yönetimin önemli ayaklarından hiyerarşi ve otoritenin toplumun icadı ve azınlığın çoğunluğu tahakküm altına alınmasında etkendir. Bu da neticesinde ekonomik köleliğin yanında zihinsel köleliğe sebebiyet vermektedir. Bu zihinsel kölelik de bireyin arzu ve isteklerini manipüle etmekte, hayal gücünü yok etmekte ve otoriter yönetiminin tahakkümünü kolaylaştırmaktadır.

\section{Sonuç}

İnsanların özellikle yerleşik hayata geçmeleri ve sonrasında yönetim olgusunun kurumsal ve düşünsel olarak ortaya çıkışıyla "mutluluk vaadi” arayışlarına tanıklık etmekteyiz. Bu bağlamda bakıldığında da tüm toplumlarda iyilik ve mutluluk sunan söylenceleri görmek mümkündür. Bu iyi bir yaşam ve mutluluk arayışlarının kavramsal olarak betimlenmesi olarak ise "ütopya” kavramı karşımıza çıkmaktadır. Ancak, ütopya kavramının birçok tanımının yapıldığı görülmektedir. Kelime 1516 yılında Thomas More'un eseriyle literatüre girmişsse de öncesinde de antik Yunandan, Ortaçağa ve günümüze değin tarihin çok çeşitli dönemlerinde ütopik bir düzen tasavvuru mevcuttur. 
Diğer yandan, ütopya ve yönetim düşüncesi arasındaki ilişki bağlamında insanlık tarihi boyunca mutluluk vaatleri olan ütopyalarda daha iyi bir düzen ve daha iyi bir yönetim isteğinin peşinden gidilmektedir ve bunu nasıl gerçekleştirilebileceği sorusunun cevabı aranır. Bu bağlamda da ütopyacıların metinlerinde farklı yönetim algılarının ve yönetim biçimlerinin bulunduğu görülmektedir. Sundukları alternatif yönetim biçimleriyle ütopyalar yönetim düşüncesini zenginleştirmekte kimi zaman da uygulamalara konu olmaktadır. Diğer bir deyişle, ütopik eserlerin yazılış amaçları yönetim ve yöneticilerle doğrudan ilişkilidir.

Ütopik sosyalistler ve anarşistlerde ise farklı yönetim düşünceleri hakimdir. Toplumla doğayı karşı karşıya getiren temel sorunların toplum ile doğa arasından kaynaklanmadığı; toplumsal gelişmenin içinden çıktığı görüşü öne çıkmaktadır (Yılıdırım, 2017:302). "Genel anlamıyla adil ve eşitlikçi bir toplumun hayata geçirilmesi için ...öncü azınlıkların çabalarının gerekli olduğunu düşünmüşlerdir” (Tunç ve Kaya, 2012:424). Simon'a göre devletin temel görevi en kalabalık ve en yoksul olan sınıfın hayat şartlarını iyileştirmesidir. Bunun için de üretimin merkezi bir şekilde örgütlenmesini, iş ordusundaki işçi mangaları, mühendis ve politekniklilerin emirleri altında bulunmasını savunur (Bumin, 2013:72).

Fourier ise falansterler ile cazibe, evrensel uyum ve tutkuların çekim yasasını temel alır. Fourier işçilerin birlikteliğinden söz eder. Falanstre arzu ve uyumun birlikte sağlanabileceği ortak yaşam mekanı olarak tasarlanır. Proudhon adem-i merkeziyet ve federalizmden bahsederek dikey örgütlenme yerine yatay örgütlenmenin ve aşağıdan yukarıya uzanacak bir yönetsel modelin hayata geçirilmesini önerir. Diğer yandan, Godwin de minimal devlete, işbirliğine, özel mülkiyetin sona erdirilmesine işaret eder.

Proudhon'dan etkilenen Kropotkin, karşılıklı yardımlaşma (mutual aid) teorisiyle Proudhon'un toplum kavramından ayrılır. Diğer yandan, “ilerici ütopyaların havasını solunamaz buluyor ve geleceğe kural konulamaz diyerek, üniformalarıyla, düzen ve disiplinleriyle her şeyleri belirlenmiş örnek komünoteleri" da eleştirmektedir. Ayrıca, Falanstre fikrinin bir kenara bırakılıp küçük evlerde yaşanılmasını önermektedir (Bumin, 2013:93-94). Bu noktada, Kropotkin de adem-i merkeziyetçi, insani ölçekte, karşılıklı yardımlaşmayı temel alan, Ortaçağ komünlerine benzer bir yönetsel düzeni hedefler. Kropotkin bütün bireylerin merkezi bir etken olacağı özgür bir yönetsel tasarım önermektedir.

Sonuç olarak bakıldığında ise farklı kaynaklardan ve farklı kültürlerden beslenen bu düşünürlerin ütopik kurgularındaki birleştirici unsur daha adil ve eşit bir toplumsal durumun sağlanmasıdır. Mevcut içinde yaşadıkları toplumdan edindikleri tecrübelerle hiyerarşik, otoriter ve iş bölümünün azınlığın lehine olduğu bir yönetsel modelin yol açtığı sorunları tespit ederek ütopik kurgularını geliştirmişlerdir. Kurgularının yönetim boyutunda, iş bölümünün daha eşitlikçi, yatay bir hiyerarşi ve otoritenin olması temel değerler olarak öne çıkmaktadır. 


\section{Kaynakça}

Avcı, M. (2006). Tommaso Campanella ve Thomas More'un Ütopyalarının Karşılaş̧tırlması, Yayınlanmamış Yüksek Lisans Tezi, Atatürk Üniversitesi, Sosyal Bilimler Enstitüsü, Erzurum

Avcı, M. (2012a). Thomas More'un Ütopyasındaki din anlayışının eleştirisi, Atatürk Üniversitesi İlahiyat Fakültesi Dergisi, 38, 289-392.

Avc1, M. (2012b). Ütopya ve kültür ilişkisi üzerine felsefi bir inceleme, F.Ü. İlahiyat Fakültesi Dergisi, 17:2, 239253.

Ayman Güler, B. (2011)."Yönetim Bilimi ya da Kamu Yönetimi: Yöntembilimsel Özellikler Üzerine", Türkiye'de Kaти Yönetimi ve Kamu Politikaları, Ed. Filiz Kartal, TODAİE Yayını No: 357, Ankara.

Bakır Şen, B. (2006). Bir Ütopyacı Olarak Sanatçının Yaşamsal Deneyimi Dönüştürme Tutkusu. Yayınlanmamış Yüksek Lisans Tezi, Çukurova Üniversitesi, Sosyal Bilimler Enstitüsü, Adana

Bal, M. (2010). Ütopyanın siyaset felsefesi tarihinde evrimi, ETHOS: Felsefe ve Toplumsal Bilimlerde Diyalog, 3:1, $1-13$.

Bookchin, M. (2013). Özgürlüğün ekolojisi: hiyerarşinin ortaya çıkışı ve çözülüşü, İstanbul: Sümer Yayınc1lı

Briefs, G.A. (1939). The Rise and Fall of the Proletarian Utopias. The Review of Politics, 1 (1), pp. 31-50.

Brinton, C. (1965). Utopia and democracy, Daedalus, 94:2, 348-366.

Bumin, K. (2013). Demokrasi arayışında kent, Konya: Çizgi Kitabevi

Cantzen, R. (2015). Daha az devlet daha çok toplum, İstanbul: Ayrıntı Yayınları

Cevizci, A. (1999). Paradigma Felsefe Sözlüğ̈̈, İstanbul: Paradigma Yayınları

De Geus, M. (2014). Peter Kropotkin's anarchist vision of organization. Ephemera: theory andpolitics in organization, 14:4, 859-877.

Fowler, R.B. (1972). The anarchist tradition of political thought, The Western Political Quarterly, 25:4, 738-752.

Güçlü, A. vd. (2003). Felsefe Sözlüğü, Ankara: Bilim ve Sanat Yayınları

Hecht, J. (1988). French utopian socialists and the population question: seeking the future, Population and Development Review, 14, 49-73

Kumar, K. (2005). Ütopyacıllk, çeviren: A. Somel, Ankara: İmge Kitabevi

Morris, JM and Kross, AL (2009). The A to Z of utopianism. The Scarecrow Press, Inc.: Lanham, Toronto, Plymouth, UK.

Proudhon, J. P (1992). Makaleler, çeviren: M. Tüzel, İstanbul: Birey yayınları, 1. Bask1

Ritter, A. (1975). Godwin, Proudhon and the anarchist justification of punishment, Political Theory, 3:1, 69-87.

Sargent, L. T. (1982). Authority and utopia: utopianism in political thought, Polity, 14:4, 565-584.

Simon, Y. and Kuic, V. (1973). A note on Proudhon's federalism, Publius, 3:1, 19-30.

Şan, Z. (2010). Ütopyalarda devlet tasarımı: Platon, Morre Campanella, Yayınlanmamış Yüksek Lisans Tezi, Çukurova Üniversitesi, Sosyal Bilimler Enstitüsü, Adana.

Şenel, A. (2001). Çağdaş Siyasal Akımlar. Ankara: İmaj Yayınevi.

Tandaçgüneş, N. (2013). Ütopya: Antik çağdan günümüze mutluluk vaadi, İstanbul Ayrıntı Yayınları.

Tunç, G. ve Kaya, Y. (2012). Doğa-kent -insan etkileşiminin dönüşümü: Ütopya ve sosyal bilim yazılarına karşılaştırmalı bir bakış, II. Uluslararası Felsefe Kongresi, Uludağ Üniversitesi, Bursa.

Ütopya, $\quad$ Erişim Tarihi:

http://www.tdk.gov.tr/index.php?option=com_gts\&arama=gts\&guid=TDK.GTS.554a1b9f1ae2c0.91280211 
Yıldırım, C. (2017). Ekoloji Düşüncesinde İnsan ve Toplum Anlayışı, İnsan ve Toplum Bilimleri Araştırmaları Dergisi, 6:1, 289-308. 